Drug Metab. Pharmacokinet. 20 (4): 227-235 (2005).

\title{
Review
}

\section{Interindividual Variability in Nicotine Metabolism: C-Oxidation and Glucuronidation}

\author{
Miki Nakajima and Tsuyoshi YokoI \\ Drug Metabolism and Toxicology, Division of Pharmaceutical Sciences, \\ Graduate School of Medical Science, Kanazawa University, Kanazawa, Japan
}

Full text of this paper is available at http://www.jstage.jst.go.jp/browse/dmpk

\begin{abstract}
Summary: Nicotine has roles in the addiction to smoking, replacement therapy for smoking cessation, as a potential medication for several diseases such as Parkinson's disease, Alzheimer's disease, and ulcerative colitis. The absorbed nicotine is rapidly and extensively metabolized and eliminated to urine. A major pathway of nicotine metabolism is $C$-oxidation to cotinine, which is catalyzed by CYP2A6 in human livers. Cotinine is subsequently metabolized to trans-3'-hydroxycotinine by CYP2A6. Nicotine and cotinine are glucuronidated to $N$-glucuronides mainly by UGT1A4 and partly by UGT1A9. Trans-3'hydroxycotinine is glucuronidated to $O$-glucuronide mainly by UGT2B7 and partly by UGT1A9. Approximately $90 \%$ of the total nicotine uptake is eliminated as these metabolites and nicotine itself. The nicotine metabolism is an important determinant of the clearance of nicotine. Recently, advances in the understanding of the interindividual variability in nicotine metabolism have been made. There are substantial data suggesting that the large interindividual differences in cotinine formation are associated with genetic polymorphisms of the $C Y P 2 A 6$ gene. Interethnic differences have also been observed in the cotinine formation and the allele frequencies of the $C Y P 2 A 6$ alleles. Since the genetic polymorphisms of the $C Y P 2 A 6$ gene have a major impact on nicotine clearance, its relationships with smoking behavior or the risk of lung cancer have been suggested. The metabolic pathways of the glucuronidation of nicotine, cotinine, and trans-3'-hydroxycotinine in humans would be one of the causal factors for the interindividual differences in nicotine metabolism. This review mainly summarizes recent results from our studies.
\end{abstract}

\section{Key words: CYP2A6; UDP-glucuronosyltransferase; genetic polymorphism; interindividual difference; ethnic difference}

\section{Introduction}

Over a billion people worldwide smoke tobacco. Smoking exerts complex central and peripheral nervous system, behavioral, cardiovascular, and endocrine effects in humans. ${ }^{1,2)}$ Smoking is associated with a higher incidence of various types of cancers, respiratory and cardiovascular disease, gastrointestinal disorders as well as many other medical complications. ${ }^{3)}$ The addiction liability and pharmacological effects of smoking are due to nicotine. Pulmonary absorption of nicotine is extremely rapid, occurring at a rate similar to that after intravenous administration. ${ }^{4)}$ The absorbed nicotine is rapidly and extensively metabolized and eliminated to urine. ${ }^{2)}$

In humans, a major pathway of nicotine metabolism is $C$-oxidation to cotinine (Fig. 1), which is catalyzed by hepatic cytochrome P4502A6 (CYP2A6). ${ }^{5)}$ Cotinine is subsequently hydroxylated to trans-3'-hydroxycotinine by CYP2A6. ${ }^{6}$ Nicotine, cotinine, and trans-3'-hydroxycotinine are glucuronidated to nicotine $N$-glucuronide, cotinine $N$-glucuronide, and trans-3' $3^{\prime}$-hydroxycotinine $O$-glucuronide, respectively. Approximately 85$95 \%$ of the total nicotine uptake is eliminated as nicotine, cotinine, trans-3'-hydroxycotinine, and their glucuronides in urine. ${ }^{7,8)}$ Other minor metabolites are nicotine $1^{\prime}-N$-oxide, cotinine $1^{\prime}-N$-oxide, nornicotine, and norcotinine. Although the nicotine $1^{\prime}-N$-oxide formation from nicotine has been reported to be catalyzed by flavin-containing monooxygenase 3 (FMO3), ${ }^{9)}$ the enzyme(s) responsible for cotinine $1^{\prime}-N$-oxide formation from cotinine is unknown. Norcotinine formation

Received; June 30, 2005, Accepted; July 20, 2005

To whom all correspondence should be sent: Miki Nakajima, Ph.D., Drug Metabolism and Toxicology, Division of Pharmaceutical Sciences, Graduate School of Medical Science, Kanazawa University, Kakuma-machi, Kanazawa 920-1192, Japan. Tel. \& Fax. +81-76-234-4407, E-mail: nmiki@kenroku.kanazawa-u.ac.jp 


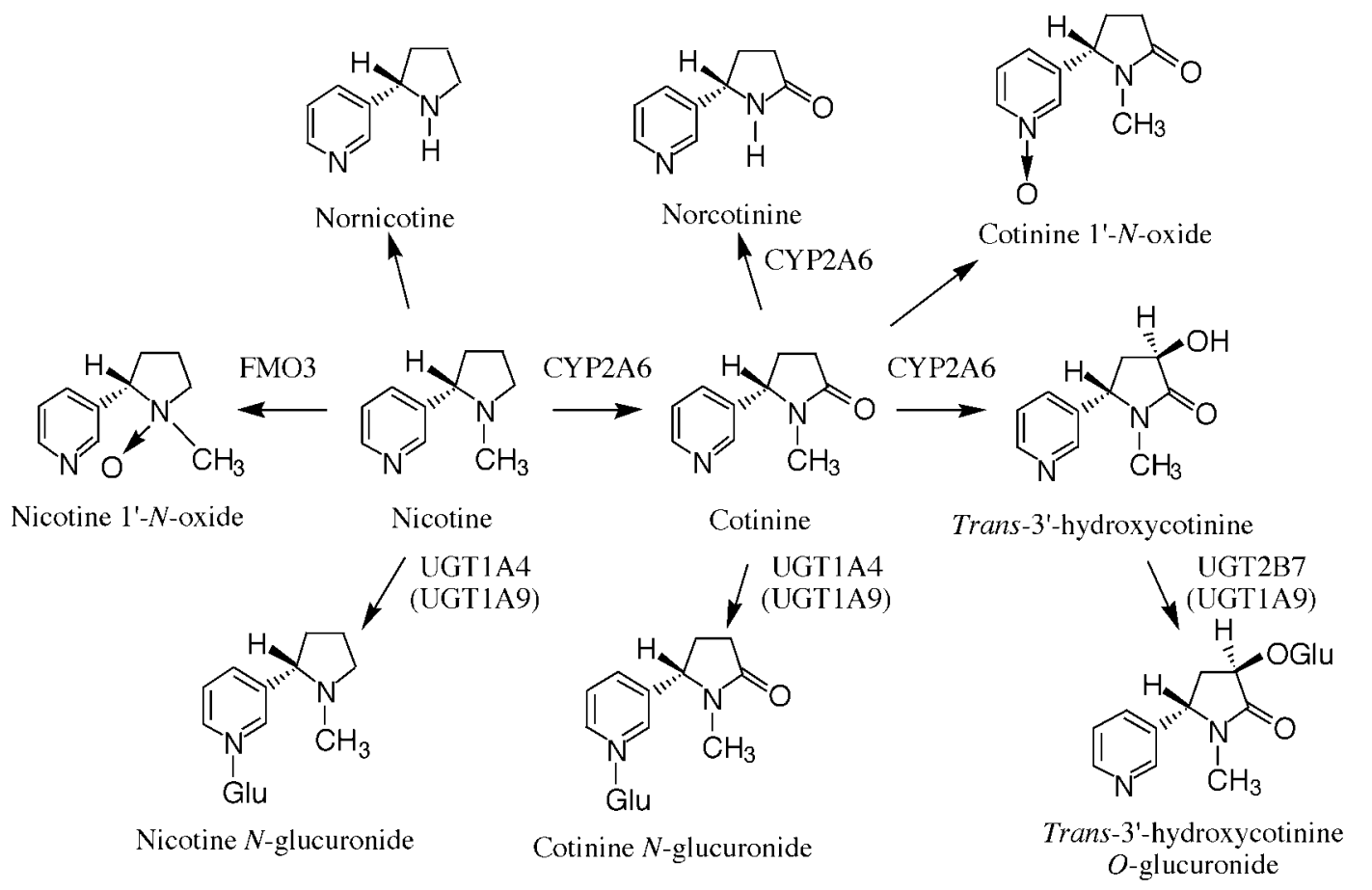

Fig. 1. Metabolic pathways of nicotine in humans.

from cotinine is catalyzed by CYP $2 \mathrm{~A} 6,{ }^{10}$ ) but the enzyme(s) responsible for nornicotine formation from nicotine is unknown.

Hepatic metabolism is the primary route of elimination of nicotine. Variability in the nicotine metabolism could be an important determinant of the clearance of nicotine. This review focuses on the interindividual differences in the major metabolic pathways, $C$-oxidation and glucuronidation, of nicotine in humans.

\section{Interindividual Differences in Cotinine Formation and Genetic Polymorphisms of CYP2A6 Gene}

Typically, $70-80 \%$ of the absorbed nicotine is metabolized to cotinine. Large interindividual variability in the cotinine formation has been demonstrated. ${ }^{11-15)}$ The half-lives of nicotine and cotinine after smoking are approximately $2 \mathrm{hr}$ and $20 \mathrm{hr}$, respectively. ${ }^{16)}$ Because of the longer half-life of cotinine, it is generally used as a biomarker of smoking. Thus, the evaluation of the metabolic potency of nicotine to cotinine in ordinary smokers would not be easy, since the cotinine levels are reflected by the extent of smoking (the number of cigarettes smoked, nicotine content per one cigarette, the depth of inhalation, and the force of drawing). We developed a simple and noninvasive method for phenotyping of nicotine metabolism to cotinine in non-smokers. ${ }^{17)}$ If smokers could abstain from smoking for about 2 weeks, this phenotyping method would be applicable. In the phenotyping method, after the subjects chewed one piece of nicotine gum, the concentrations of nicotine and cotinine in the plasma $2 \mathrm{hr}$ after the chewing were determined. Consequently, large interindividual differences were observed in the cotinine/nicotine ratios calculated as the metabolic index. In Japanese $(n=92)$ and Korean $(n=209)$ populations, the cotinine/nicotine ratios ranged from 0 to 14.7 and 0 to 143.9 , respectively. ${ }^{18,19)}$ Similar large interindividual differences have been also observed in European-American and African-American populations with this phenotyping method. The results of our comprehensive analyses for interindividual and interethnic differences in cotinine formation will soon be reported.

Cotinine formation from nicotine is catalyzed by CYP2A6. ${ }^{5)}$ There is genetic polymorphism in the human CYP2A6 gene (http://www.imm.ki.se/CYPalleles/ cyp2a6.htm). Several mutated alleles have been reported to decrease or delete the enzymatic activity (Table 1). $C Y P 2 A 6^{*} 4$ allele, in which the entire $C Y P 2 A 6$ gene is deleted, completely lacks the enzymatic activity. ${ }^{20-22)}$ Alleles possessing a single nucleotide polymorphism (SNP), such as $C Y P 2 A 6^{*} 2(\mathrm{~L} 160 \mathrm{H}){ }^{23)} C Y P 2 A 6^{*} 5$ (G479V), ${ }^{24)} \quad C Y P 2 A 6^{*} 6 \quad(\mathrm{R} 128 \mathrm{Q}),{ }^{14)} \quad C Y P 2 A 6^{*} 7$ $(\mathrm{I} 471 \mathrm{~T}),{ }^{25)} C Y P 2 A 6^{*} 9$ (T-48G in TATA box), ${ }^{26)}$ $C Y P 2 A 6^{*} 10,{ }^{15,27)}$ and $C Y P 2 A 6^{*} 11$ (S224P), ${ }^{28)}$ have been reported to lead to decreased enzymatic activity in vitro and/or in vivo. In our studies, the relationship between the interindividual differences in nicotine metabolism to cotinine and genetic polymorphisms of the $C Y P 2 A 6$ gene in Japanese and Korean subjects was 
Table 1. Characteristics of human $C Y P 2 A 6$ allele

\begin{tabular}{|c|c|c|c|c|c|}
\hline \multirow{2}{*}{ Allele } & \multicolumn{2}{|c|}{ Nucleotide changes } & \multirow{2}{*}{ Effect } & \multicolumn{2}{|c|}{ Enzyme activity } \\
\hline & cDNA & Gene & & In vivo & In vitro \\
\hline$C Y P 2 A 6^{*} 1 A$ & None & None & & Normal & Normal \\
\hline$C Y P 2 A 6^{*} 1 B$ & $\begin{array}{l}\text { gene conversion in the } \\
3^{\prime} \text {-flanking region }\end{array}$ & $\begin{array}{l}-1013 \mathrm{~A}>\mathrm{G} \text { : } \\
\text { gene conversion in the } \\
3^{\prime} \text {-flanking region }\end{array}$ & & & \\
\hline$C Y P 2 A 6^{*} 1 C$ & $\begin{array}{l}\text { gene conversion in the } \\
3^{\prime} \text {-flanking region }\end{array}$ & $\begin{array}{l}-395 \mathrm{G}>\mathrm{A}: \\
\text { gene conversion in the } \\
3^{\prime} \text {-flanking region }\end{array}$ & & & \\
\hline$C Y P 2 A 6^{*} 1 D$ & & $-1013 A>G$ & & & \\
\hline$C Y P 2 A 6^{*} 1 E$ & $\begin{array}{r}\text { gene c } \\
3^{\prime}-\mathrm{fl}\end{array}$ & $\begin{array}{l}\text { n in the } \\
\text { region }\end{array}$ & & & \\
\hline$C Y P 2 A 6^{*} 1 F$ & $1224 \mathrm{C}>\mathrm{T}$ & $5717 \mathrm{C}>\mathrm{T}$ & & & \\
\hline$C Y P 2 A 6^{*} 1 G$ & $1224 \mathrm{C}>\mathrm{T}$ & $5717 \mathrm{C}>\mathrm{T} ; 5825 \mathrm{~A}>\mathrm{G}$ & & & \\
\hline$C Y P 2 A 6^{*} 1 H$ & & $-745 \mathrm{~A}>\mathrm{G}$ & & & \\
\hline$C Y P 2 A 6^{*} 1 J$ & & $-1013 \mathrm{~A}>\mathrm{G} ;-745 \mathrm{~A}>\mathrm{G}$ & & & \\
\hline$C Y P 2 A 6^{*} 1 X 2$ & & & gene duplication & & \\
\hline$C Y P 2 A 6^{*} 2$ & $51 \mathrm{G}>\mathrm{A} ; 479 \mathrm{~T}>\mathrm{A}$ & $51 \mathrm{G}>\mathrm{A} ; 1799 \mathrm{~T}>\mathrm{A}$ & $\mathrm{L} 160 \mathrm{H}$ & None & None \\
\hline$C Y P 2 A 6^{*} 3$ & $C Y P 2 A$ & $A 7$ hybrid & & & \\
\hline $\mathrm{CYP} 2 \mathrm{~A}^{*} 4$ & $C Y$ & eleted & CYP2A6 deleted & None & \\
\hline$C Y P 2 A 6^{*} 5$ & $\begin{array}{l}1436 \mathrm{G}>\mathrm{T} \text {; } \\
\text { gene conversion in } \\
\text { the } 3^{\prime} \text {-flanking region }\end{array}$ & $\begin{array}{l}6582 \mathrm{G}>\mathrm{T} \text {; } \\
\text { gene conversion in } \\
\text { the } 3^{\prime} \text {-flanking region }\end{array}$ & G479V & None & None \\
\hline$C Y P 2 A 6^{*} 6$ & $383 \mathrm{G}>\mathrm{A}$ & $1703 \mathrm{G}>\mathrm{A}$ & $\mathrm{R} 128 \mathrm{Q}$ & & Decreased \\
\hline$C Y P 2 A 6^{*} 7$ & $\begin{array}{l}1412 \mathrm{~T}>\mathrm{C} \text {; } \\
\text { gene conversion in the } \\
3^{\prime} \text {-flanking region }\end{array}$ & $\begin{array}{l}6558 \mathrm{G}>\mathrm{C} \text {; } \\
\text { gene conversion in the } \\
3^{\prime} \text {-flanking region }\end{array}$ & $\mathrm{I} 471 \mathrm{~T}$ & Decreased & Decreased \\
\hline$C Y P 2 A 6^{*} 8$ & $\begin{array}{l}1454 \mathrm{G}>\mathrm{T} \text {; } \\
\text { gene conversion in the } \\
3^{\prime} \text {-flanking region }\end{array}$ & $\begin{array}{l}6600 \mathrm{G}>\mathrm{T} \\
\text { gene conversion in the } \\
3^{\prime} \text {-flanking region }\end{array}$ & $\mathrm{R} 485 \mathrm{~L}$ & Normal & \\
\hline$C Y P 2 A 6^{*} 9$ & & $-1013 \mathrm{~A}>\mathrm{G} ;-48 \mathrm{~T}>\mathrm{G}$ & TATA box & Decreased & Decreased \\
\hline$C Y P 2 A 6^{*} 10$ & $\begin{array}{l}1412 \mathrm{~T}>\mathrm{C} \text {; } \\
1454 \mathrm{G}>\mathrm{T} ; \\
\text { gene conversion in the } \\
3^{\prime} \text {-flanking region }\end{array}$ & $\begin{array}{l}6558 \mathrm{~T}>\mathrm{C} ; \\
6600 \mathrm{G}>\mathrm{T} ; \\
\text { gene conversion in the } \\
3^{\prime} \text {-flanking region }\end{array}$ & I471T; R485L & Decreased & \\
\hline$C Y P 2 A 6^{*} 11$ & $670 \mathrm{~T}>\mathrm{C}$ & $3391 \mathrm{~T}>\mathrm{C}$ & S224P & Decreased & Decreased \\
\hline$C Y P 2 A 6^{*} 12$ & $\begin{array}{l}\text { exons } 1-2 \\
\text { exons } 3-9\end{array}$ & $\begin{array}{l}2 A 7 \text { origin; } \\
2 A 6 \text { origin }\end{array}$ & $\begin{array}{l}10 \text { amino acid } \\
\text { substitutions }\end{array}$ & Decreased & Decreased \\
\hline$C Y P 2 A 6^{*} 13$ & $13 \mathrm{G}>\mathrm{A}$ & $-48 \mathrm{~T}>\mathrm{G} ; 13 \mathrm{G}>\mathrm{A}$ & G5R & & \\
\hline CYP $2 A 6^{*} 14$ & $51 \mathrm{G}>\mathrm{A} ; 86 \mathrm{G}>\mathrm{A}$ & $51 \mathrm{G}>\mathrm{A} ; 86 \mathrm{G}>\mathrm{A}$ & S29N & & \\
\hline$C Y P 2 A 6^{*} 15$ & $580 \mathrm{~A}>\mathrm{G}$ & $-48 \mathrm{~T}>\mathrm{G} ; 2134 \mathrm{~A}>\mathrm{G}$ & K194E & & \\
\hline$C Y P 2 A 6^{*} 16$ & $607 \mathrm{C}>\mathrm{A}$ & $2161 \mathrm{C}>\mathrm{A}$ & R203S & & \\
\hline$C Y P 2 A 6^{*} 17$ & $\begin{array}{l}459 \mathrm{G}>\mathrm{A} ; 1093 \mathrm{G}>\mathrm{A} \\
1224 \mathrm{C}>\mathrm{T}\end{array}$ & $\begin{array}{l}209>\mathrm{T} ; 1779 \mathrm{G}>\mathrm{A} \\
4489 \mathrm{C}>\mathrm{T} ; 5065 \mathrm{G}>\mathrm{A} \\
5163 \mathrm{G}>\mathrm{A} ; 5717 \mathrm{C}>\mathrm{T} \\
5825 \mathrm{~A}>\mathrm{G}\end{array}$ & V365M & Decreased & Decreased \\
\hline$C Y P 2 A 6^{*} 18$ & $1175 \mathrm{~A}>\mathrm{T}$ & $5668 \mathrm{~A}>\mathrm{T}$ & Y392F & & Decreased \\
\hline CYP $2 A 6^{*} 19$ & $\begin{array}{l}1175 \mathrm{~A}>\mathrm{T} ; 1412 \mathrm{~T}>\mathrm{C} ; \\
\text { gene conversion in the } \\
3^{\prime} \text {-flanking region }\end{array}$ & $\begin{array}{l}5668 \mathrm{~A}>\mathrm{T} ; 6354 \mathrm{~T}>\mathrm{C} ; \\
6558 \mathrm{~T}>\mathrm{C} ; \\
\text { gene conversion in the } \\
3^{\prime} \text {-flanking region }\end{array}$ & Y392F; I471T & & Decreased \\
\hline$C Y P 2 A 6^{*} 20$ & $\begin{array}{l}51 \mathrm{G}>\mathrm{A} ; 587-588 \text { delAA; } \\
1191 \mathrm{~T}>\mathrm{C} ; 1546 \mathrm{C}>\mathrm{G}\end{array}$ & $\begin{array}{l}51 \mathrm{G}>\mathrm{A} ; 2141-2142 \text { delAA; } \\
2296 \mathrm{C}>\mathrm{T} ; 5684 \mathrm{~T}>\mathrm{C} \\
6692 \mathrm{C}>\mathrm{G}\end{array}$ & Frameshift & & None \\
\hline$C Y P 2 A 6^{*} 21$ & $51 \mathrm{G}>\mathrm{A} ; 1427 \mathrm{~A}>\mathrm{G}$ & $51 \mathrm{G}>\mathrm{A} ; 6573 \mathrm{~A}>\mathrm{G}$ & K476R & & \\
\hline$C Y P 2 A 6^{*} 22$ & $\begin{array}{l}51 \mathrm{G}>\mathrm{A} ; 474 \mathrm{C}>\mathrm{G} \\
478 \mathrm{C}>\mathrm{A}\end{array}$ & $\begin{array}{l}51 \mathrm{G}>\mathrm{A} ; 1794 \mathrm{C}>\mathrm{G} \\
1798 \mathrm{C}>\mathrm{A}\end{array}$ & D158E; L160I & & \\
\hline
\end{tabular}

determined. ${ }^{18,27,29)}$ In Asian populations, the allele frequencies of $C Y P 2 A 6^{*} 4$ (11-20\%), CYP2A6*7 (4-7\%), and $C Y P 2 A 6^{*} 9$ (20\%) were relatively high. The CYP $2 A 6^{*} 5 \quad(\sim 0.5 \%), C Y P 2 A 6^{*} 6 \quad(\sim 0.4 \%)$, $C Y P 2 A 6^{*} 10(0.5-1.1 \%)$, and $C Y P 2 A 6^{*} 11(\sim 0.7 \%)$ alleles were rare, and the $C Y P 2 A 6^{*} 2$ allele was not found. ${ }^{30,31)} \mathrm{We}$ found that cotinine formation was impaired in the homozygotes of either $C Y P 2 A 6^{*} 4$, $C Y P 2 A 6^{*} 7$ and $C Y P 2 A 6^{*} 10$ (Fig. 2). ${ }^{18,19,27)}$ In particular, cotinine was not detected in the plasma $2 \mathrm{hr}$ after nicotine intake in subjects who are homozygotes of $C Y P 2 A 6^{*} 4 . C Y P 2 A 6^{*} 9$, possessing a SNP in the TATA box, has been reported to decrease the transcriptional activity in vitro. ${ }^{26)}$ We also found that the $C Y P 2 A 6^{*} 9$ 
allele caused decreased expression levels of CYP2A6 mRNA and protein in vitro, and decreased the nicotine metabolism in vivo. ${ }^{29)}$

In contrast to Asian populations, the $C Y P 2 A 6^{*} 2$ allele, which lacks the enzymatic activity, has been found in Europeans, European-Americans, and African-Americans, although the allele frequencies are not so high $(0.3-2.2 \%)$. $C Y P 2 A 6^{*} 9$ has also been found in these populations with moderate frequencies (7.1$8.5 \%)$. Recently, we found novel alleles, $C Y P 2 A 6^{*} 17$ $(10.4 \%)$ and $C Y P 2 A 6^{*} 20(1.6 \%)$, that are specific for the African-American population. ${ }^{32,33)}$ Since the

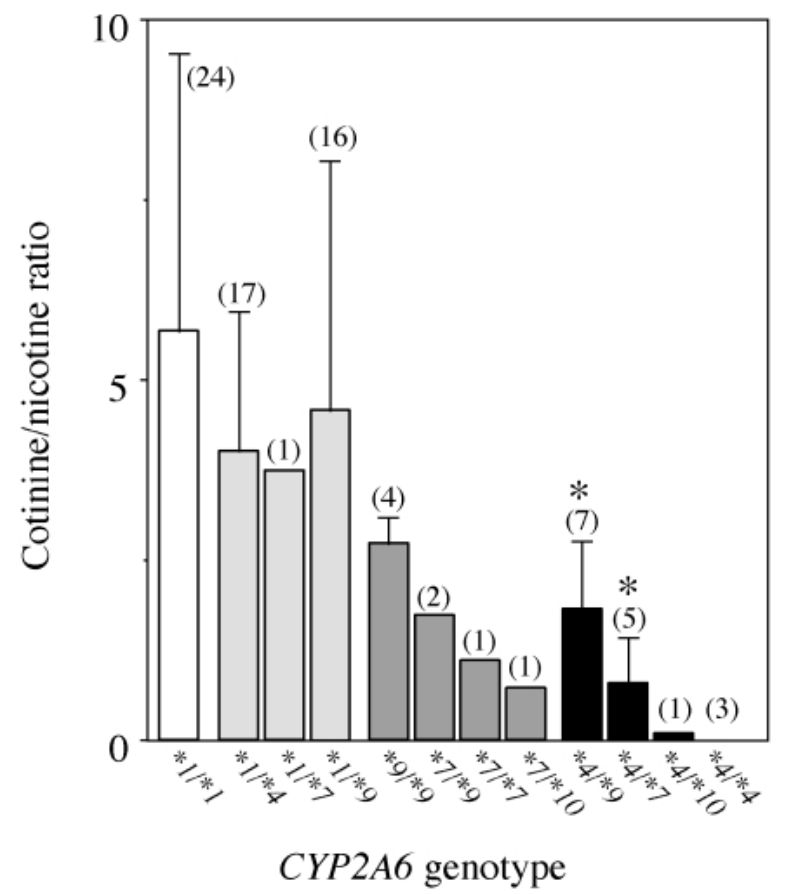

Fig. 2. Cotinine/nicotine ratios in Japanese subjects who were genotyped for $C Y P 2 A 6$ alleles. The numbers of subjects are shown in parentheses. Data are expressed as mean \pm SD. ${ }^{*} P<0.05$, compared with $C Y P 2 A 6^{*} 1 / C Y P 2 A 6^{*} 1$.

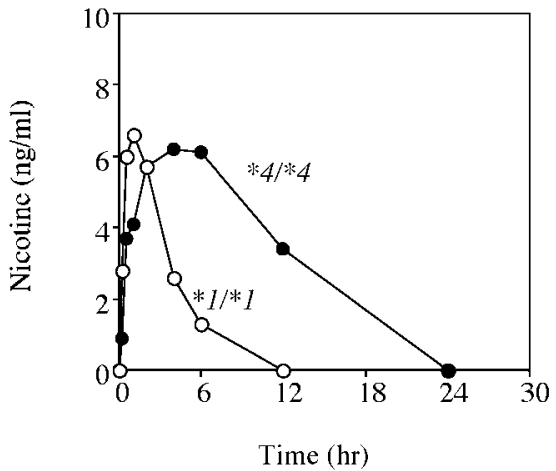

CYP2A6*17 allele (V365M) decreases the enzymatic activity and the $C Y P 2 A 6^{*} 20$ allele (frameshift) lacks the activity, African-American subjects with these alleles showed low cotinine formation in vivo. ${ }^{32,33)}$ In summary, the large interindividual variability of cotinine formation from nicotine can be mostly explained by genetic polymorphisms of the $C Y P 2 A 6$ gene. Smokers adapt their smoking behavior to maintain their plasma nicotine concentration..$^{2)}$ The metabolism of nicotine to cotinine is the principal pathway by which active nicotine is removed from the circulation. ${ }^{34)}$ Associations between genetic polymorphisms of the $C Y P 2 A 6$ gene and smoking behavior or the risk of lung cancer have also been suggested. ${ }^{35-37)}$

\section{Effects of CYP2A6 Deletion on Comprehensive Nicotine Metabolism}

In homozygotes of the $C Y P 2 A 6^{*} 4$ allele, cotinine was not detected in the plasma $2 \mathrm{hr}$ after nicotine intake. ${ }^{18,19)}$ The AUC values of cotinine in the subjects were prominently lower (one fifteenth) than those in subjects who possess the two active $C Y P 2 A 6$ alleles (Fig. 3). ${ }^{17)}$ In homozygotes of the $C Y P 2 A 6^{*} 4$ allele, the half-life of nicotine $(2 \mathrm{hr})$ was prolonged to $11 \mathrm{hr} .{ }^{17)}$ To elucidate the nicotine metabolism in the subjects whose $C Y P 2 A 6$ gene is deleted, the urinary excretion profile of nicotine metabolism was determined by a liquid chromatography tandem mass spectrometry (LC-MS/MS) method. ${ }^{38)}$ In that study, 5 Japanese subjects who were genotyped for the $C Y P 2 A 6$ gene participated. They chewed one piece of nicotine gum, and 24-hr accumulated urine samples were analyzed for nicotine metabolites. Out of 5 subjects, 3 subjects were genotyped as $C Y P 2 A 6^{*} 1 A /$ $C Y P 2 A 6^{*} 1 A, \quad C Y P 2 A 6^{*} 1 A / C Y P 2 A 6^{*} 1 B, \quad$ and $C Y P 2 A 6^{*} 1 A / C Y P 2 A 6^{*} 4$. Since the $C Y P 2 A 6^{*} 1 B$ allele has a gene conversion with $C Y P 2 A 7$ in the $3^{\prime}$-untranslated region, ${ }^{24)}$ it is considered that the enzymatic activity is the same as that of $C Y P 2 A 6^{*} 1 A .^{24,29,39)}$ Previously, we found that heterozygotes of the $C Y P 2 A 6^{*} 4$ allele

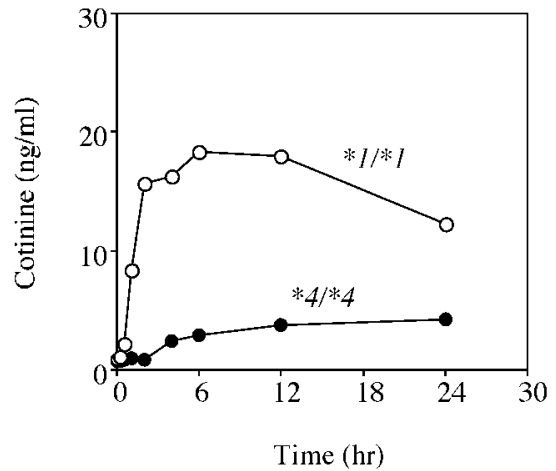

Fig. 3. Plasma concentrations of nicotine and cotinine in Japanese subjects who were genotyped as $C Y P 2 A 6^{*} 1 / C Y P 2 A 6^{*} 1$ or $C Y P 2 A 6^{*} 4 /$ $C Y P 2 A 6^{*} 4$. They chewed one piece of nicotine gum containing $2 \mathrm{mg}$ of nicotine for $30 \mathrm{~min}$. 
CYP2A6 genotype

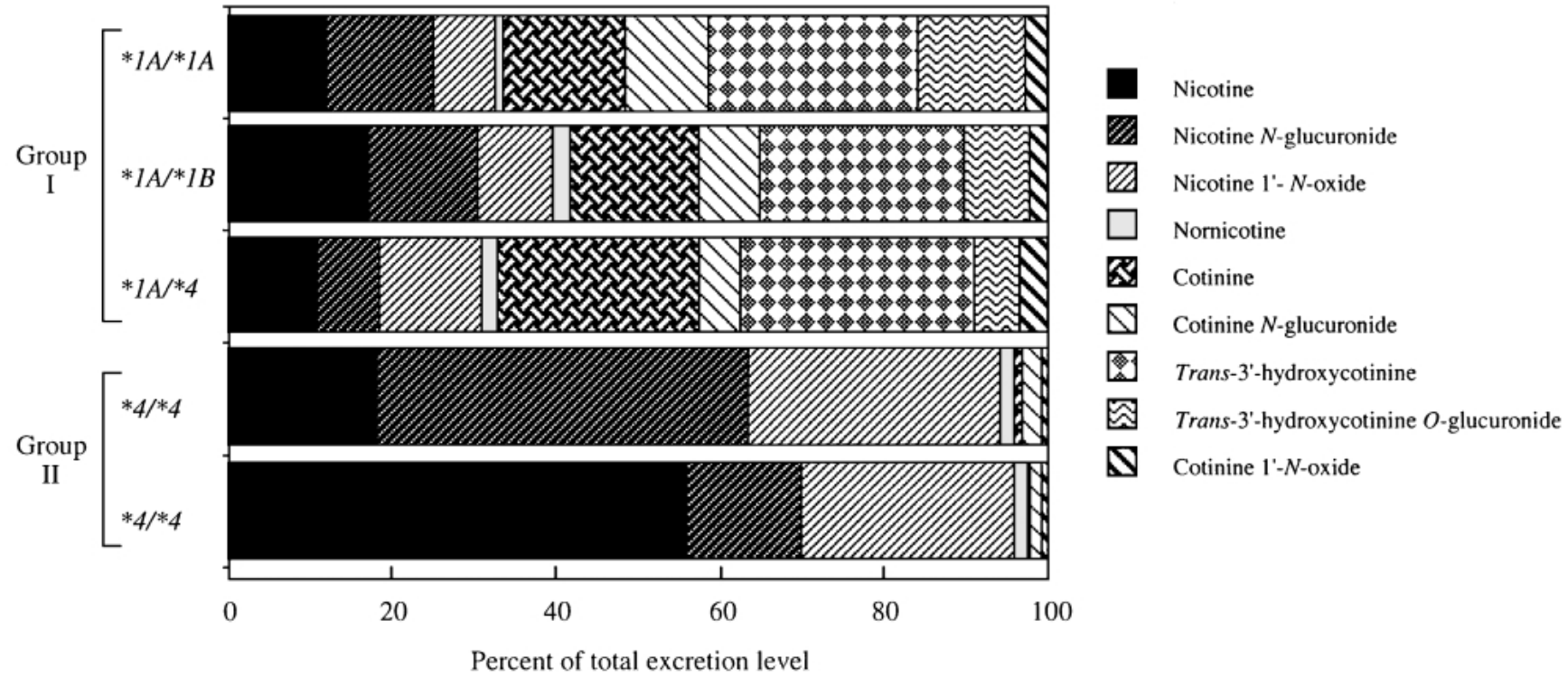

Fig. 4. Excretion levels of nicotine and its metabolites in 24-hr accumulated urine samples. $C Y P 2 A 6$ genotypes in 5 subjects were determined. Three subjects genotyped as $C Y P 2 A 6^{*} 1 A / C Y P 2 A 6^{*} 1 A, C Y P 2 A 6^{*} 1 A / C Y P 2 A 6^{*} 1 B$, and $C Y P 2 A 6^{*} 1 A / C Y P 2 A 6^{*} 4$ were categorized as group I. Two subjects genotyped as $C Y P 2 A 6^{*} 4 / C Y P 2 A 6^{*} 4$ were categorized as group II. Norcotinine was not detected in any subjects.

can metabolize nicotine at levels similar to those of homozygotes of $C Y P 2 A 6^{*} 1 A .^{18,19)}$ Therefore, these 3 subjects were categorized as group I (two or one active allele). Two subjects who were genotyped as $C Y P 2 A 6^{*} 4 / C Y P 2 A 6^{*} 4$ were categorized as group II (none active allele).

Consistent with a previous report, ${ }^{40}$ ) nicotine was mainly excreted as cotinine, trans-3'-hydroxycotinine, and their glucuronides in the 3 subjects of group I (Fig. 4). The sums of cotinine and cotinine-derived metabolites were $58.1-66.9 \%$ of the total excretion. The results support those of a previous report that $70-80 \%$ of nicotine is converted to cotinine. ${ }^{7)}$ In contrast, only trace levels of cotinine, cotinine $\mathrm{N}$-glucuronide, and cotinine $1^{\prime}-N$-oxide were detected in the 2 subjects of group II, whereas trans-3'-hydroxycotinine and its $O$-glucuronide were not detected. It is considered that these results were due to the deletion of the entire CYP2A6 gene in the 2 subjects. Although cotinine formation from nicotine is mainly catalyzed by CYP2A6, we previously found that CYP2B6 and CYP2D6 also possess trivial catalytic activity toward cotinine formation. ${ }^{5)}$ It has also been reported that the $\mathrm{Km}$ value of the cotinine formation by recombinant CYP2B6 was 10 fold higher than that by recombinant CYP2A6. ${ }^{41)}$ Thus, the cotinine would be formed compensatorily by these CYPs in the 2 subjects whose $C Y P 2 A 6$ gene is deleted. The fact that no trans-3'hydroxycotinine and its $O$-glucuronide could be detected in the subjects supports our previous data that CYP2A6 specifically catalyzes trans-3'-hydroxycotinine formation from cotinine. ${ }^{6}$ In the 2 subjects of group II, the excretion levels of nicotine, nicotine $N$-glucuronide, and nicotine $1^{\prime}-N$-oxide were higher than those in the 3 subjects of group I. The sum of the excretion levels of nicotine and all metabolites were similar between group I (mean, 3,967 nmol) and group II (mean, 4,033 nmol). It has been reported that nicotine is absorbed by buccal $(0.8 \mathrm{mg})$ and gut $(0.06 \mathrm{mg})$ after the chewing of one piece of nicotine gum containing $2 \mathrm{mg}$ of nicotine. ${ }^{42)}$ The expected absorbed nicotine of $0.86 \mathrm{mg}$ corresponds to $5,306 \mathrm{nmol}$. Thus, it is assumed that most of the absorbed nicotine would be excreted in $24 \mathrm{hr}$, although the ingredients of the excreted metabolites were different between group I and group II. It was demonstrated that the metabolic profile of nicotine was affected by the deletion of CYP2A6, which is mainly responsible for nicotine metabolism.

\section{Nicotine and Cotinine $\mathrm{N}$-Glucuronidations}

Glucuronidation is an important pathway of nicotine metabolism in humans. The average percentages of nicotine $\mathrm{N}$-glucuronide and cotinine $\mathrm{N}$-glucuronide excreted in smokers' urine were approximately 3-4\% and $9-17 \%$ of the nicotine absorbed, respectively. ${ }^{7,8,43)}$ The metabolic pathway of glucuronidation would be one of the causal factors for the interindividual differences in nicotine metabolism. Indeed, considerable interindividual variability in the percentages of the conjugates of nicotine $(3.8-56.0 \%)$ and cotinine $(0-60.3 \%)$ in urine has been reported. ${ }^{7)}$

Nicotine and cotinine $\mathrm{N}$-glucuronidations in human 
A

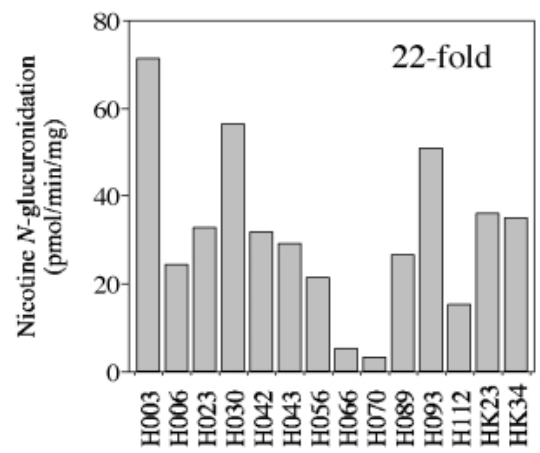

B

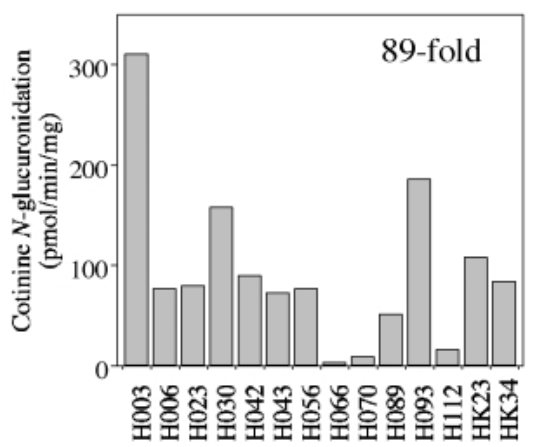

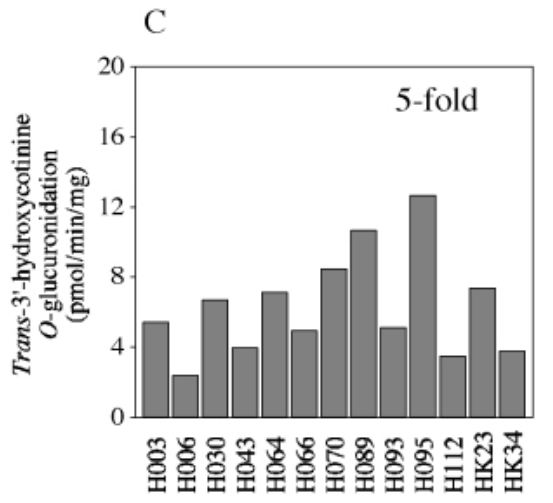

Fig. 5. Interindividual variability in nicotine $N$-glucuronidation (A), cotinine $N$-glucuronidation (B), and trans-3'-hydroxycotinine $O$-glucuronidation (C) in human liver microsomes. Human liver microsomes $(0.25 \mathrm{mg} / \mathrm{mL}$ microsomal protein) were incubated with $2.5 \mathrm{mM}$ UDP-glucuronic acid and $50 \mu \mathrm{M}$ nicotine, $0.2 \mathrm{mM}$ cotinine, or $1 \mathrm{mM}$ trans- $3^{\prime}$-hydroxycotinine at $37^{\circ} \mathrm{C}$ for $60 \mathrm{~min}$. Each column represents the mean of duplicate determinations.

liver microsomes were characterized thoroughly in our study. ${ }^{44)}$ The kinetics of nicotine $N$-glucuronidation in human liver microsomes were clearly biphasic, whereas those of cotinine $\mathrm{N}$-glucuronidation were monophasic. Based on the highly significant correlation between the nicotine $N$-glucuronidation and cotinine $N$-glucuronidation in human liver microsomes, the same UDPglucuronosyltransferase (UGT) isoform(s) might be involved in these glucuronidations. We clarified that nicotine and cotinine $N$-glucuronidation are catalyzed mainly by UGT1A4 and partly by UGT1A9 with inhibition analyses and correlation analyses, ${ }^{44)}$ which were subsequently supported in a report by Kuehl and Murphy. ${ }^{45)}$

Large interindividual variability in the nicotine $\mathrm{N}$ glucuronidation ( $\sim 22$ fold) and cotinine $N$-glucuronidation ( $\sim 89$ fold) in human liver microsomes was observed (Fig. 5). In addition, Benowitz et al. ${ }^{46)}$ reported that the in vivo nicotine and cotinine $N$-glucuronidations appeared to be polymorphic in black subjects, although these were unimodal in white subjects. For all UGT isoforms, there are genetic polymorphisms. Recently, genetic polymorphisms of UGT1A4 that affect the enzymatic activity have been reported. ${ }^{47-49)}$ Therefore, genetic polymorphisms of the UGT1 isoforms might be one of the causal factors of the interindividual differences in nicotine and cotinine $N$ glucuronidation in humans. Furthermore, it has been reported that UGT1A9 is inducible by polycyclic aromatic hydrocarbons that are contained in cigarette smoke. ${ }^{50)}$ The inducibility of UGTs by cigarette smoke might affect the interindividual differences in nicotine and cotinine $N$-glucuronidations. Conclusive explanations for the interindividual and interethnic differences in the nicotine and cotinine $\mathrm{N}$-glucuronidations remain to be found.

\section{Trans-3' -hydroxycotinine $\boldsymbol{O}$-Glucuronidation}

Trans-3'-hydroxycotinine $O$-glucuronide is a major metabolite of nicotine in smokers' urine. Nicotine and cotinine are metabolized to $N$-glucuronide, whereas trans-3' ${ }^{\prime}$-hydroxycotinine is metabolized to $O$-glucuronide in vivo. $N$-Linked glucuronide of trans-3'-hydroxycotinine was detected by incubation with human liver microsomes, ${ }^{51,52)}$ although it has never been detected in smokers' urine. ${ }^{52,53)}$ Since the trans-3' -hydroxycotinine $N$-glucuronidation was significantly correlated with the nicotine and cotinine $N$-glucuronidations, it may be catalyzed by UGT1A $4 .{ }^{51,52)}$

We characterized the trans-3'-hydroxycotinine $O$ glucuronidation in human liver microsomes and identified the human UGT isoform(s) involved in the glucuronidation. Recombinant UGT2B7 exhibited the highest trans-3'-hydroxycotinine $O$-glucuronosyltransferase activity, followed by UGT1A9, UGT2B15, and UGT2B4. Trans-3'-hydroxycotinine $O$-glucuronidation in human liver microsomes was significantly correlated with valproic acid glucuronidation, which is catalyzed by UGT2B7, UGT1A6, and UGT1A9. ${ }^{54)}$ Trans-3'hydroxycotinine $O$-glucuronidation in human liver microsomes was inhibited by imipramine (UGT1A4), propofol (UGT1A9), and androstanediol (UGT2B15). However, it was confirmed that these three compounds inhibited trans-3' -hydroxycotinine $O$-glucuronosyltransferase activity catalyzed by recombinant UGT2B7 with more potent inhibitory effects than those in human liver microsomes. In addition, we found that the morphine 3glucuronosyltransferase activity catalyzed by recombinant UGT2B7 was also inhibited by imipramine, propofol, and androstanediol. In contrast, imipramine and androstanediol did not affect the trans-3'-hydroxycotinine $O$-glucuronosyltransferase activity catalyzed by recombinant UGT1A9. These results suggest that the 
major UGT isoform involved in trans-3'-hydroxycotinine $O$-glucuronidation in human liver microsomes would be UGT2B7. Although morphine glucuronidation is catalyzed by UGT2B7,${ }^{55}$ ) the correlation with trans-3'-hydroxycotinine $O$-glucuronidation was not significant. It might be due to the contribution of other UGT isoforms such as UGT1A9 to the trans-3'-hydroxycotinine $O$-glucuronidation. Tobacco specific nitrosamine, 4-(methylnitrosamino)-1-(3-pyridyl)-1-butanol, has been reported to be metabolized to its $O$ glucuronide by UGT1A9 and UGT2B $7^{56}$ and its $N$ glucuronide by UGT1A4. ${ }^{57)}$ Thus, the specificity of the UGT isoform for $\mathrm{O}$ - or $\mathrm{N}$-glucuronidations of trans-3' hydroxycotinine would be similar to that for 4-(methylnitrosamino)-1-(3-pyridyl)-1-butanol.

Interindividual variability in the trans-3'-hydroxycotinine $O$-glucuronosyltransferase activities in microsomes from 13 human livers was at most 5 fold (Fig. 5). It was not so large, compared with those in the nicotine and cotinine $N$-glucuronidation in the panel of human liver microsomes. The results suggest that the interindividual variability of the expression level or activity of UGT2B7 might be lower than those of other UGT isoforms. Alternatively, the involvement of multiple enzymes in the trans-3'-hydroxycotinine $O$-glucuronosyltransferase might reduce the interindividual variability.

\section{Conclusion}

Variability in nicotine metabolism could be an important determinant of nicotine clearance. Recent advances in nicotine metabolism research have elucidated some of the causes for the large interindividual differences in metabolic capacity. Special emphasis is given to the effects of the genetic polymorphisms of $C Y P 2 A 6$ gene in relation to the interindividual differences in the nicotine metabolism to cotinine. Interindividual variability has been also observed in the glucuronidation pathways of nicotine and its metabolites. The identification of UGT isoforms involved in the glucuronidations could be helpful for the consideration of such interindividual variability. The causes of the interindividual and interethnic differences in the glucuronidations of nicotine and its metabolites, in relation to the genetic polymorphisms of UGTs or regulation of their expressions, will be studied in the future.

Acknowledgments: We are grateful to Dr. Yukio Kuroiwa, Showa University for his encouragement and helpful suggestions. The authors' work summarized in this review was supported by an SRF Grant for Biomedical Research in Japan, a grant from Japan Health Sciences Foundation with Research on Health Science focusing on Drug Innovation, and by Philip Morris Incorporated. We acknowledge Mr. Brent Bell for reviewing the manuscript.

\section{References}

1) Vial, W. C.: Cigarette smoking and lung disease. Am. J. Med. Sci., 291: 130-142 (1986).

2) Benowitz, N. L.: Drug therapy. Pharmacologic aspects of cigarette smoking and nicotine addiction. N. Engl. J. Med., 319: 1318-1330 (1988).

3) Lee, E. W. and D'Alonzo, G. E.: Cigarette smoking, nicotine addiction, and its pharmacologic treatment. Arch. Intern. Med., 153: 34-48 (1993).

4) Russell, M. A. H. and Feyerabend, C.: Cigarette smoking: A dependence on high-nicotine boli. Drug Metab. Rev., 8: 29-57 (1978).

5) Nakajima, M., Yamamoto, T., Nunoya, K., Yokoi, T., Nagashima, K., Inoue, K., Funae, Y., Shimada, N., Kamataki, T. and Kuroiwa, Y.: Role of human cytochrome P4502A6 in C-oxidation of nicotine. Drug Metab. Dispos., 24: 1212-1217 (1996).

6) Nakajima, M., Yamamoto, T., Nunoya, K., Yokoi, T., Nagashima, K., Inoue, K., Funae, Y., Shimada, N., Kamataki, T. and Kuroiwa, Y.: Characterization of CYP2A6 involved in $3^{\prime}$-hydroxylation of cotinine in human liver microsomes. J. Pharmacol. Exp. Ther., 277: 1010-1015 (1996).

7) Benowitz, N. L., Jacob, P. III., Fong, I. and Gupta, S.: Nicotine metabolic profile in man: comparison of cigarette smoking and transdermal nicotine. J. Pharmacol. Exp. Ther., 268: 296-303 (1994).

8) Byrd, G. D., Chang, K.-M., Greene, J. M. and deBethizy, J. D.: Evidence for urinary excretion of glucuronide conjugates of nicotine, cotinine, and trans3'-hydroxycotinine in smokers. Drug Metab. Dispos., 20: 192-197 (1992).

9) Cashman, J. R., Park, S. B., Yang, Z-C., Wrighton, S. A., Jacob, P. III. and Benowitz, N. L.: Metabolism of nicotine by human liver microsomes: stereoselective formation of trans-nicotine $N^{\prime}$-oxide. Chem. Res. Toxicol., 5: 639-646 (1992).

10) Murphy, S. E., Johnson, L. M. and Pullo, D. A.: Characterization of multiple products of cytochrome P450 2A6-catalyzed cotinine metabolism. Chem. Res. Toxicol., 12: 639-645 (1999).

11) Cholerton, S., Arpanahi, A., McCracken, N., Boustead, C., Taber, H., Johnstone, E., Leathart, J., Daly, A. K. and Idle, J. R.: Poor metabolisers of nicotine and CYP2D6 polymorphism. Lancet, 343: 62-63 (1994).

12) Benowitz, N. L., Jacob, P. III. and Sachs, D. P.: Deficient $C$-oxidation of nicotine. Clin. Pharmacol. Ther., 57: 590-594 (1995).

13) Rao, Y., Hoffmann, E., Zia, M., Bodin, L., Zeman, M., Sellers, E. M. and Tyndale, R. F.: Duplications and defects in the $C Y P 2 A 6$ gene: identification, genotyping, and in vivo effects on smoking. Mol. Pharmacol., 58: 747-755 (2000).

14) Kitagawa, K., Kunugita, N., Kitagawa, M. and Kawamoto, T.: $C Y P 2 A 6^{*} 6$, a novel polymorphism in cytochrome P450 2A6, has a single amino acid substitution (R128Q) that inactivates enzymatic activity. J. Biol. Chem., 276: 17830-17835 (2001).

15) Xu, C., Rao, Y. S., Xu, B., Hoffmann, E., Jones, J., 
Sellers, E. M. and Tyndale, R. F.: An in vivo pilot study characterizing the new $C Y P 2 A 6^{*} 7, * 8$, and *10 alleles. Biochem. Biophys. Res. Commun., 290: 318-324 (2002).

16) Scherer, G., Jarczyk, L., Heller, W. D., Biber, A., Neurath, G. B. and Adlkofer, F.: Pharmacokinetics of nicotine, cotinine, and $3^{\prime}$-hydroxycotinine in cigarette smokers. Klin. Wochenschr., 66 Suppl 11: 5-11 (1988).

17) Nakajima, M., Yamagishi, S., Yamamoto, H., Yamamoto, T., Kuroiwa, Y. and Yokoi, T.: Deficient cotinine formation from nicotine is attributed to the whole deletion of the CYP2A6 gene in humans. Clin. Pharmacol. Ther., 67: 57-69 (2000).

18) Nakajima, M., Kwon, J.-T., Tanaka, N., Zenta, T., Yamamoto, Y., Yamamoto, H., Yamazaki, H., Yamamoto, T., Kuroiwa, Y. and Yokoi, T.: Relationship between interindividual differences in nicotine metabolism and CYP2A6 genetic polymorphism in humans. Clin. Pharmacol. Ther., 69: 72-78 (2001).

19) Kwon, J.-T., Nakajima, M., Chai, S., Yom, Y.-K., Kim, H.-K, Yamazaki, H., Sohn, D.-R., Yamamoto, T., Kuroiwa, Y. and Yokoi, T.: Nicotine metabolism and CYP2A6 allele frequencies in Koreans. Pharmacogenetics, 11: 317-323 (2001).

20) Nunoya, K., Yokoi, T., Kimura, K., Kainuma, T., Satoh, K., Kinoshita, M. and Kamataki, T.: A new CYP2A6 gene deletion responsible for the in vivo polymorphic metabolism of $(+)$-cis-3,5-dimethyl2-(3-pyridyl)thiazolidin-4-one hydrochloride in humans. J. Pharmacol. Exp. Ther., 289: 437-442 (1999).

21) Nunoya, K., Yokoi, T., Takahashi, K., Kimura, K., Kinoshita, M. and Kamataki, T.: Homologous unequal cross-over within the human $C Y P 2 A$ gene cluster as a mechanism for the deletion of the entire $C Y P 2 A 6$ gene associated with the poor metaboliser phenotype. $J$. Biochem., 126: 402-407 (1999).

22) Oscarson, M., McLellan, R. A., Gullsten, H., Yue, Q. Y., Lang, M. A., Bernal, M. L., Sinues, B., Hirvonen, A., Raunio, H., Pelkonen, O. and Ingelman-Sundberg, M.: Characterization and PCR-based detection of $C Y P 2 A 6$ gene deletion found at a high frequency in a Chinese population. FEBS Lett., 448: 105-110 (1999).

23) Yamano, S., Tatsuno, J. and Gonzalez, F. J.: The $C Y P 2 A 3$ gene product catalyzes coumarin 7-hydroxylation in human liver microsomes. Biochemistry, 29: 1322-1329 (1990).

24) Oscarson, M., McLellan, R. A., Gullsten, H., Agundez, J. A., Benitez, J., Rautio, A., Raunio, H., Pelkonen, O. and Ingelman-Sundberg, M.: Identification and characterization of novel polymorphisms in the CYP2A locus: implications for nicotine metabolism. FEBS Lett., 460: 321-327 (1999).

25) Ariyoshi, N., Sawamura, Y. and Kamataki, T.: A novel single nucleotide polymorphism altering stability and activity of CYP2A6. Biochem. Biophys. Res. Commun., 281: 810-814 (2001).

26) Pitarque, M., von Richter, O., Oke, B., Berkkan, H., Oscarson, M. and Ingelman-Sundberg, M.: Identification of a single nucleotide polymorphism in the TATA box of the CYP2A6 gene: impairment of its promoter activity. Biochem. Biophys. Res. Commun., 284:
455-460 (2001).

27) Yoshida, R., Nakajima, M., Watanabe, Y., Kwon, J.-T. and Yokoi, T.: Genetic polymorphisms in human CYP2A6 gene causing impaired nicotine metabolism. Br. J. Clin. Pharmacol., 54: 511-517 (2002).

28) Daigo, S., Takahashi, Y., Fujieda, M., Ariyoshi, N., Yamazaki, H., Koizumi, W., Tanabe, S., Saigenji, K., Nagayama, S., Ikeda, K., Nishioka, Y. and Kamataki, T.: A novel mutant allele of the CYP2A6 gene $\left(C Y P 2 A 6^{*} 11\right)$ found in a cancer patient who showed poor metabolic phenotype towards tegafur. Pharmacogenetics, 12: 299-306 (2002).

29) Yoshida, R., Nakajima, M., Nishimura, K., Tokudome, S., Kwon, J.-T. and Yokoi, T.: Effects of polymorphism in promoter region of human $C Y P 2 A 6$ gene $\left(C Y P 2 A 6^{* 9}\right)$ on expression level of messenger ribonucleic acid and enzymatic activity in vivo and in vitro. Clin. Pharmacol. Ther., 74: 69-76 (2003).

30) Nakajima, M., Kuroiwa, Y. and Yokoi, T.: Interindividual differences in nicotine metabolism and genetic polymorphisms of human CYP2A6. Drug Metab. Rev., 34: 865-877 (2002).

31) Hukkanen, J., Jacob, P. III. and Benowitz, N. L.: Metabolism and disposition kinetics of nicotine. Pharmacol. Rev., 57: 79-115 (2005).

32) Fukami, T., Nakajima, M., Yoshida, R., Tsuchiya, Y., Fujiki, Y., Katoh, M., McLeod, H. L. and Yokoi, T.: A novel polymorphism of human CYP2A6 gene $C Y P 2 A 6^{*} 17$ has an amino acid substitution (V365M) that decreases enzymatic activity in vitro and in vivo. Clin. Pharmacol. Ther., 76: 519-527 (2004).

33) Fukami, T., Nakajima, M., Higashi, E., Yamanaka, H., McLeod, H. L. and Yokoi, T.: A novel $C Y P 2 A 6^{*} 20$ allele found in African-American population produces a truncated protein lacking enzymatic activity. Biochem. Pharmacol., in press (2005).

34) Kyerematen, G. A. and Vesell, E. S.: Metabolism of nicotine. Drug Metab. Rev., 23: 3-41 (1991).

35) Tyndale, R. F. and Sellers, E. M.: Variable CYP2A6mediated nicotine metabolism alters smoking behavior and risk. Drug Metab. Dispos., 29: 548-552 (2001).

36) Ariyoshi, N., Miyamoto, M., Umetsu, Y., Kunitoh, H., Dosaka-Akita, H., Sawamura, Y., Yokota, J., Nemoto, N., Sato, K. and Kamataki, T.: Genetic polymorphism of $C Y P 2 A 6$ gene and tobacco-induced lung cancer risk in male smokers. Cancer Epidemiol. Biomarkers Prev., 11: 890-894 (2002).

37) Fujieda, M., Yamazaki, H., Saito, T., Kiyotani, K., Gyamfi, M. A., Sakurai, M., Dosaka-Akita, H., Sawamura, Y., Yokota, J., Kunitoh, H. and Kamataki, T.: Evaluation of $C Y P 2 A 6$ genetic polymorphisms as determinants of smoking behavior and tobacco-related lung cancer risk in male Japanese smokers. Carcinogenesis, 25: 2451-2458 (2004).

38) Yamanaka, H., Nakajima, M., Nishimura, K., Yoshida, R., Fukami, T., Katoh, M. and Yokoi, T.: Metabolic profile of nicotine in subjects whose $C Y P 2 A 6$ gene is deleted. Eur. J. Pharm. Sci., 22: 419-425 (2004).

39) Ariyoshi, N., Takahashi, Y., Miyamoto, M., Umetsu, Y., Daigo, S., Tateishi, T., Kobayashi, S., Mizorogi, Y., 
Loriot, M. A., Stucker, I., Beaune ,P., Kinoshita, M. and Kamataki, T.: Structural characterization of a new variant of the $C Y P 2 A 6$ gene $\left(C Y P 2 A 6^{*} 1 B\right)$ apparently diagnosed as heterozygotes of $C Y P 2 A 6^{*} 1 A$ and CYP2A6*4C. Pharmacogenetics, 10: 687-693 (2000).

40) Tricker, A. R.: Nicotine metabolism, human drug metabolism polymorphisms, and smoking behavior. Toxicology, 183: 151-173 (2003).

41) Yamazaki, H., Inoue, K., Hashimoto, M. and Shimada, T.: Roles of CYP2A6 and CYP2B6 in nicotine $C$-oxidation by human liver microsomes. Arch. Toxicol., 73: 65-70 (1999).

42) Benowitz, N. L., Jacob, P. III. and Savanapridi, C.: Determinants of nicotine intake while chewing nicotine polacrilex gum. Clin. Pharmacol. Ther., 41: 467-473 (1987).

43) Curvall, M., Vala, E. K. and Englund, G.: Effects of nicotine on biological systems. In Adlkofer, F. and Thurau, K. (eds.): Advances in Pharmacological Sciences, Boston, Birkhauser Verlag, 1991, pp. 69-75.

44) Nakajima, M., Tanaka, E., Kwon, J.-T. and Yokoi, T.: Characterization of nicotine and cotinine $N$-glucuronidations in human liver microsomes. Drug Metab. Dispos., 30: 1484-1490 (2002).

45) Kuehl, G. E. and Murphy, S. E.: $N$-Glucuronidation of nicotine and cotinine by human liver microsomes and heterologously expressed UDP-glucuronosyltransferases. Drug Metab Dispos., 31: 1361-1368 (2003).

46) Benowitz, N. L., Perez-Stable, E. J., Fong, I., Modin, G., Herrera, B. and Jacob, P. III.: Ethnic differences in $N$-glucuronidation of nicotine and cotinine. J. Pharmacol. Exp. Ther., 291: 1196-1203 (1999).

47) Ehmer, U., Vogel, A., Schutte, J. K., Krone, B., Manns, M. P. and Strassburg, C. P.: Variation of hepatic glucuronidation: Novel functional polymorphisms of the UDP-glucuronosyltransferase UGT1A4. Hepatology, 39: 970-977 (2004).

48) Mori, A., Maruo, Y., Iwai, M., Sato, H. and Takeuchi, Y.: UDP-glucuronosyltransferase 1A4 polymorphisms in a Japanese population and kinetics of clozapine glucuronidation. Drug Metab. Dispos., 33: 672-675 (2005).

49) Saeki, M., Saito, Y., Jinno, H., Sai, K., Hachisuka, A.,
Kaniwa, N., Ozawa, S., Kawamoto, M., Kamatani, N., Shirao, K., Minami, H., Ohtsu, A., Yoshida, T., Saijo, N., Komamura, K., Kotake, T., Morishita, H., Kamakura, S., Kitakaze, M., Tomoike, H. and Sawada, J.: Genetic variations and haplotypes of UGT1A4 in a Japanese population. Drug Metab. Pharmacokinet., 20: 144-151 (2005).

50) Bock, K. W., Gsxhaidmeier, H., Heel, H., Lehmköster, T., Münzel, P. A. and Bock-Hennig, B. S: Functions and transcriptional regulation of PAH-inducible human UDP-glucuronosyltransferase. Drug Metab. Rev., 31: 411-422 (1999).

51) Kuehl, G. E. and Murphy, S. E.: $N$-Glucuronidation of trans-3'-hydroxycotinine by human liver microsomes. Chem Res. Toxicol., 16: 1502-1506 (2003).

52) Yamanaka, H., Nakajima, M., Katoh, M., Kanoh, A., Tamura, O., Ishibashi, H. and Yokoi, T.: Trans-3'hydroxycotinine $O$ - and $N$-glucuronidations in human liver microsomes. Drug Metab. Dispos., 33: 23-30 (2005).

53) Byrd, G. D., Uhrig, M. S., deBethizy, J. D., Caldwell, W. S., Crooks, P. A., Ravard, A. and Riggs, R.: Direct determination of cotinine- $N$-glucuronide in urine using thermospray liquid chromatography/mass spectrometry. Biol. Mass Spectrom. 23: 103-107 (1994).

54) Ethell, B. T., Anderson, G. D. and Burchell, B.: The effect of valproic acid on drug and steroid glucuronidation by expressed human UDP-glucuronosyltransferases. Biochem. Pharmacol., 65: 1441-1449 (2003).

55) Coffman, B. L., Rios, G. R., King, C. D. and Tephly, T. R.: Human UGT2B7 catalyzes morphine glucuronidation. Drug Metab. Dispos., 25: 1-4 (1997).

56) Ren, Q., Murphy, S. E. and Lazarus, P.: O-Glucuronidation of the lung carcinogen 4-(methylnitrosamino)-1(3-pyridyl)-1-butanol (NNAL) by human UDPglucuronosyltransferases 2B7 and 1A9. Drug Metab. Dispos., 28: 1352-1360 (2000).

57) Wiener, D., Doerge, D. R., Fang, J. L., Upadhyaya, P. and Lazarus, P.: Characterization of $N$-glucuronidation of the lung carcinogen 4-(methylnitrosamino)-1-(3pyridyl)-1-butanol (NNAL) in human liver: importance of UDP-glucuronosyltransferase 1A4. Drug Metab. Dispos., 32: 72-79 (2004). 